\title{
Managing White Spot Lesion During and After The Orthodontic Treatment
}

\author{
Fatama Siddika ${ }^{1} \quad$ BDS \\ Mohammad Sayedur Rahman Khan ${ }^{2}$ BDS \\ Ren Jia Bao ${ }^{3}$ \\ Ma Wen Sheng ${ }^{4}$
}

\begin{abstract}
The constitution of enamel demineralization or white spot lesion (WSL) at the side of fixed orthodontic appliance is a usual complexity seen at the period of fixed orthodontic treatment and after completion of this treatment, which scupper the accomplishment of a successfully completed case. Restraining programmes for managing this orthodontic side effect must be accentuated for all orthodontic patients. The concern of an orthodontist is to abate the risk of decalcification as a sequence of orthodontic treatment by instructing and motivating the patients for good oral hygiene care. Recognition of WSL before the orthodontic treatment might allow performing preventive measures to counteract the process of progression of lesion. Modern strategies of managing WSL during and after the orthodontic treatment are reviewed coevally in this article. This review represents the prevention and management of white spot lesion by topical fluoride releasing materials (bonding agent resin modified glass ionomer cements [RMGICs], toothpaste, gel, mouthwash, varnishes), pro-biotic, polyols, antiseptic, sealants, casein supplements, laser, tooth bleaching agent, micro-abrasion and resin infiltration which are effectual. Nevertheless the implementation of RMGICs, casein phosphopeptide amorphous calcium phosphate, micro-abrasion, resin infiltration can be more adjuvant than only the fluoride rinses in the abatement of white spot lesion or demineralization spots.
\end{abstract}

KEY WORDS: White spot lesion, Fluoride bonding agent RMGICs, Casein phosphopeptide amorphous calcium phosphate, Resin infiltration.

HOW TO CITE: Siddika F, Khan MSR, Bao RJ, Sheng MW. Managing white spot lesion during and after the orthodontic treatment. J Pak Dent Assoc 2018;27(1):1-8.

DOI: https://doi.org/10.25301/JPDA.271.1

Received: 20 December, 2017, Accepted: 31 January, 2018

\section{INTRODUCTION}

$\mathrm{O}$ rthodontic fixed appliances and enamel demineralization have a strong relation with each other in orthodontic treatment. Enamel demineralization is the initial exposure of carious lesion which can be identified with naked eye as white spot lesion (WSL). ${ }^{1}$ In most cases it located at the side of the bands and brackets (Figure-1, Figure-2). This initial lesion can extend to cavitated lesion from enamel to dentin. Diagnosis of this lesion can be done by Meticulous visual examination, the white intensity as well as limit and opacity features under

1. Orthodontics \& Dentofacial Orthopedics department, College of Stomatology, Hebei Medical University.

2. Oral \& Maxillofacial Surgery department, College of Stomatology, Hebei Medical University.

3. Orthodontics \& Dentofacial Orthopedics department, College of Stomatology, Hebei Medical University.

4. Professor \& Head of Department, Orthodontics \& Dentofacial Orthopedics Department, College of Stomatology, Hebei Medical University.

Corresponding author: "Prof. Ma Wen Sheng"<798311029@qq.com> transillumination. On the basis of diagnosis this lesion can be classified into following types: superficial(non-cavitated), mixed(non-cavitated and cavitated ) and deep (cavitated).

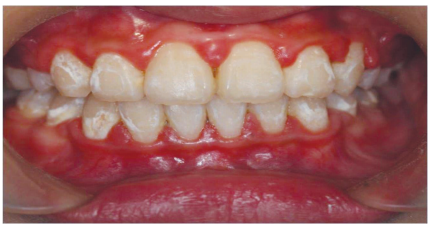

Figure-1: White spot lesions after orthodontic treatment with fixed appliances (frontal view).

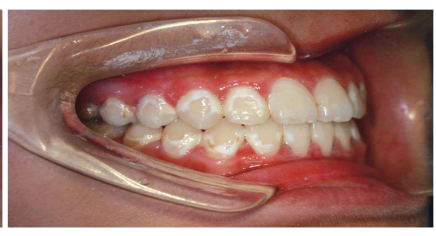

Figure-2: White spot lesions after orthodontic treatment with fixed appliances (lateral view).
These lesions are non fluoridated opacities with defined shape and well differentiated from surrounding enamel. It is usually seen in the orthodontic treatment due to improper oral hygiene. Oral hygiene is impeded by orthodontic appliances (e.g. bands, brackets, wires) which create retention areas for dental plaque because of their irregular surfaces as well as making chance to elongate the retention of plaque 
on surfaces of teeth. ${ }^{2-6}$ This elongation of plaque retention along with acidogenic bacteria such as streptococcus mutans, and various lactobacilli play a momentous role in the development of enamel demineralization or white spot lesion. ${ }^{7-8}$ Previous clinical study showed WSLs occurrence highly increase in first 6 months of treatment and continuing slowly up to 12 months, for this reason appropriate maintenance of oral hygiene is consulted at the starting of the orthodontic treatment. ${ }^{9}$ Other factors associated with higher risk of WSLs are younger age, prolong treatment duration, percentage of treatment time in elastomeric chain, number of missed appointments, patients with malocclusion, number of poor oral hygiene excerpt in the patient chart, poor attending, male gender and poor oral hygiene at the screening examination. ${ }^{10}$ The aesthetic purpose of treatment is hampered by this white spot lesion. ${ }^{6,11-13}$ Improving facial and dental aesthetic is the first priority of all Orthodontist which can mar with the appearance of white spot lesion after removal of orthodontic appliances. Hence Orthodontist and patient ought to treat to impede the formation of white spot lesions. Several techniques for the management of WSLs during and after the orthodontic treatment are implemented, but the foremost one is still controversial. This side effect of orthodontic treatment affects patient's aesthetic as well as smile and can be very difficult or sometimes even impossible to eradicate after detaching fixed appliances. After completion of orthodontic treatment, the appearance of WSLs is about $50 \%$ and the aim of all Orthodontist is to annihilate WSLs. ${ }^{14-20}$ Prevalence of WSLs usually associated with the labio-buccal surfaces of maxillary teeth with this manner - lateral incisors, canines, premolars and central incisors. ${ }^{21,22}$ Earlier study showed that WSLs occur both on labial and lingual surfaces of teeth. ${ }^{23}$ WSLs mostly found on maxillary anterior segment and very few on maxillary posterior segments, in addition females are less affected then male. ${ }^{24}$ Incidence and prevalence of WSLs between right and left sides of the maxilla and mandible do not have any special difference. ${ }^{25-27}$ The aim of this study is to oversee the ways of managing WSLs based on the current information during and after the orthodontic treatment.

\section{PATHOGENESIS OF WSLS}

The term WSL was defined as "Caries like lesion which can be seen on enamel by naked eye as first sign". ${ }^{28}$ Remarkable alteration usually happen in concentration of acidogenic bacteria (especially Streptococcus mutans and lactobacilli) while orthodontic appliances are applied into the oral cavity. Orthodontic patient with plaque of higher concentration of acidogenic bacteria has greater extent in comparison with other patients which causes progressive caries. $^{29}$

\section{ETIOLOGY}

The prevalence of WSL on the enamel surface is caused by multiple factors in the period of fixed orthodontic treatment. Presence of bacterial plaque, fermentable carbohydrates, a susceptible tooth surface and a sufficient period of time are necessary for the formation of WSL. Many irregularities are present in the fixed appliance of orthodontic treatment which causes easy accumulation of food debris along with the cariogenic bacteria and cause the manual teeth cleansing more difficult as well as also avert the selfcleansing action of tongue, lips and cheeks to remove accumulated food debris from the tooth surfaces. The gingival side of brackets are the area of great plaque deposition. ${ }^{30}$ Elastomeric rings ligated teeth have greater number of cariogenic microorganism arrangements which can be seen fewer in stainless steel ligature wires ligated teeth. ${ }^{31}$

\section{PREVENTION AND MANAGEMENT OF WSLS}

The prevention and management of white spot lesions can be achieved by applying multifunctional approaches during orthodontic treatment.

\section{Mechanical plaque control methods for improving patient oral hygiene}

The most important prophylactic measure is maintenance of good oral hygiene to prevent the occurrence of WSLs in orthodontic patient. The commencement of prevention can be achieved by educating and motivating the patient to noncariogenic diet as well as by observing of oral hygiene for compliance. Tooth brushing of tooth surfaces daily two times at least, with fluoride containing toothpaste is highly advised for mechanical Plaque controlling and removing the plaque from retaining areas. For attaining patient good oral hygiene a standard modified tooth brush, uses of disclosing solutions and floss can aid. More effective method of reduction of plaque accumulation might be daily water irrigation or use of a power toothbrush in combination with manual tooth brushing than manual tooth brushing only. ${ }^{32}$ To enhance the brushing efficacy and facilitating the patient cleaning as well as to reduce the bacterial load, professional prophylactic cleaning is quite effective. Professional tooth cleaning two or three times yearly can abate the risk of caries in number of teeth and keep up a healthy mouth. The inaccessible areas which are difficult to brush for the patient can be properly cleaned by professional tooth cleaning. Polishing of the coronal surfaces by progressively finer particle size fluoridated 
pastes and brushes or polishing elastomer cups can prevent the bacterial mechanical retention. ${ }^{33}$

\section{Enamel resistance can be increased against the microbial acids by applying topical fluoride}

Complacent action of fluoride in resisting WSLs has been proved with the uses of the followings such as fluoride mouthwashes, fluoride gel, fluoride toothpaste, fluoride varnishes, fluoride in bonding agents and fluoride in elastomers. White spot lesions/dental caries can be impeded at early stages by fluoride ions through several mechanisms like alteration of bacterial metabolism of dental plaque through inhibition of some enzymatic processes, inhibition of production of acids, alteration of the composition of bacterial flora and/or the metabolic activity of microorganisms; and decreasing demineralization as well as increasing re-mineralization of white spot lesion. ${ }^{34}$

\section{Fluoride containing bonding agent}

Risk of caries increases in case of prolong orthodontic treatment patient. If the bonding system incessantly releases fluoride at the side of bracket base, it would be immensely adjuvant. Resin modified glass ionomer cements (RMGICs) have been proposed as bracket bonding agents due to their continuous fluoride releasing properties throughout the orthodontic treatment. RMGICs continuously take up fluoride from the environment (e.g. fluoride in dentifrices, in oral rinse and in potable fluoridated water), act as pumps and precisely re-release fluoride to the most prone areas of WSLs. The application of RMGICs is performed in the following manner - first enamel de-proteinization (to remove the surface organic layer) is done by application of $5.25 \%$ sodium hypochlorite (NaOCL) on enamel surface for $1 \mathrm{~min}$ and then etched with $37 \%$ phosphoric acid for 30 s, this creates type 1 etching pattern (the enamel rod, or prism, heads are dissolved) and type 2 etching pattern (in which the enamel inter-prismatic substance is dissolved) forms micro-porosities of increase number which allow the bonding agent (RMGICs) to penetrate the enamel surface for enhancing the bracket bonding rate of success (by increasing shear bond strength [SBS]) as well as serve the added benefit of minimizing WSL development.

\section{Fluoride containing Toothpaste}

Fluoride toothpaste containing either one of these (sodium fluoride, monoflourophosphate, stannous fluoride) or a combination of these compounds is recommended. In comparison with normal formulation (more than $1000 \mathrm{ppm}$ ) the $5000 \mathrm{ppm}$ concentration of fluoride in toothpaste is more effective to treat WSL. ${ }^{35-37}$ Due to the application of fluoride ion on enamel surface a fluoroapatite crystal structure is formed which is less soluble with hydroxyapatite in the oral environment. Use of fluoride toothpaste is mostly recommended regularly to the patients by the orthodontist as they are at high risk of WSLs, only fluoride toothpaste uses is not effective in resisting WSL in the majority of patients, even with good oral hygiene implementation of other sources fluoride together with fluoride tooth paste is recommended. $5,38-43$

\section{Flouride containing mouthwashes}

Everyday uses of fluoridated mouthwash (contain $0.05 \%$ sodium fluoride) caused significant abatement of the lesion formation at the side of brackets and beneath the bands. Nowadays antimicrobial agents like chlorhexidine, zinc, triclosan conjoin with mouthwashes to enhance cariostatic effects. Previous study recommended, prevention of enamel demineralization during fixed orthodontic treatment by the everyday used of $0.05 \% \mathrm{NaF}$ mouthwash has the best strategy, ${ }^{44}$ also everyday rinsing mouth with $\mathrm{NaF} 0.05 \%$ or $0.2 \%$ and/or weekly rinse with AFP $(1.2 \%)$ have been observed reducing WSLs incidence during active fixed orthodontic treatment. ${ }^{45}$ Fluoride concentration in the saliva significantly increased if $\mathrm{NaF}$ mouthwash uses for 2 week (one rinse per day). ${ }^{44}$

\section{Fluoride containing gel}

Use of 1100ppm fluoride toothpaste together with $0.4 \%$ stannous fluoride gel applied twice daily by toothbrush, both provide additional protection against decalcification. ${ }^{46}$

\section{Fluoride containing pits and fissure sealants}

Placing of light cured pit and fissure sealants adjacent to bonded orthodontic brackets on the labial/buccal surface were $80 \%$ effective in resisting white spot lesion was found in vitro and required no patient compliance. ${ }^{47}$ It is quite difficult to remove the sealant and after removal it needs precision polishing.

\section{Fluoride varnish}

The efficacy of fluoride varnishes have proved largely in decreasing the incidence of caries. In poorly-motivated patients, this varnish can be applied with an intensive treatment schedule (every three to four monthly). Remission of demineralization of the enamel at the side of brackets, enhancing re-mineralization of the carious lesions as well as impediment of further lesions can be achieved by the fluoride varnishes. Inspite of patient's noncompliance, topical fluoride varnish is quite advantageous for preventing WSLs and delivering the fluoride in a sustained manner over a longer period of time. Biannually Duraphate applying to WSLs areas showed $30-50 \%$ reduction in comparison with 
the non-varnished areas. ${ }^{48}$ Application of fluoride varnish with excellent oral hygiene to prevent WSLs has been proved as fast and simple technique.

\section{Additional method's different mechanisms Probiotics}

Pro-biotics are live microorganisms with health benefits when they are administered in adequate numbers inhibit other microorganisms, especially pathogens. Probiotic bacteria might enhance effect of fluoride in preventing dental caries. ${ }^{49}$

\section{Polyols}

Polyols are weakly metabolized (sorbitol) or nonmetabolized (xylitol) by cariogenic bacteria. Chewing gum with xylitol ( $2 \mathrm{~g}$ of xylitol/socket) or polyols is recommended after each meal (three times daily) for 10-20 min. ${ }^{45-52}$ Previous study reported that xylitol lozenges significantly decreased the acidity of dental plaque in fixed orthodontic appliance patients after consumption of sucrose. ${ }^{50}$

\section{Antiseptic (Chlorohexidine varnish)}

Chlorohexidine is available in different presentation like mouthwashes, gel or varnishes. Chlorohexidine varnishes are more effective than its gels and mouthwashes, chlorohexidine varnish reduces streptococcus mutans levels in orthodontic patients with fixed appliances and therefore might be useful to prevent carious lesion.53When combining chlorohexidine varnish with a fluoride varnish (Fluor Protector), the cariostatic effect becomes enhanced even in comparison to ozone, which also can decrease streptococcus mutans count.54

\section{Use of casein phosphopeptides amorphous calcium phosphate}

Recent research has shown that casein phosphopeptidesamorphous calcium phosphate (CPP-ACP) absorb through the enamel surface and affected the demineralization-remineralization processes,${ }^{55}$ this processes is performed by $\mathrm{CPP}$ which is derived from casein protein and contains calcium and phosphate ions "stuck" to create CPP-ACP. The calcium and phosphate ions are provided by this CPP-ACP and shows anti-cariogenic activity on tooth surface, thereabout CPP-ACP knows as store house of calcium and phosphate..$^{53}$ The calcium and phosphate ions are released while the occurrence of intraoral acid attack and aid the saliva to obtain a supersaturated state of ions which precipitate a calciumphosphate compound on the exposed tooth surface. ${ }^{56}$ In addition, ammonia is produced by the disintegration of the $\mathrm{CPP}$ lead to increase the $\mathrm{pH}$ (buffer) and delays formation of bio-film by preventing bacterial adhesion to tooth surfaces. ${ }^{57}$ In CPP-ACP mechanism, deeper penetration of ions results the entire body re-mineralization of the lesion inspite of acting only on the surface layer, thus the aesthetic appearance improves. A recent study showed that application of CPP-ACP-containing varnish to incisors, with or without brushing and use of a mouthwash, decreased the depth of carious lesions around orthodontic brackets. ${ }^{58}$

\section{Lasers}

Laser beams increase enamel micro-hardness and resistance to acid attack. In preventive dentistry the argon lasers, CO2, Nd-YAG, and erbium YAG are used..$^{50,59,60}$ Irradiation of enamel decreases amount of demineralization up to $30 \%-50 \%$ with argon laser beams, ${ }^{61}$ laser beams also lowered the dissolution threshold $\mathrm{pH}$ value. Laser beams maintain an intact enamel surface but cause surface morphology changes. Exposure to laser beams micro-spaces form within the enamel, the released ions trap into these micro-spaces and act as re-mineralization sites within the enamel surface. The mean lesion depth is significantly reduced by the application of argon laser beams (488 nm) compared to visible light controls. ${ }^{62}$

\section{AFTER ORTHODONTIC TREATMENT}

After the removal of fixed orthodontic appliances, a regressive appearance of WSLs might be seen because of salivary radical re-mineralization as well as brushing abrasion and such progress relies on the severity of lesions. ${ }^{63}$ Nevertheless this WSLs re-mineralization is not sufficient to overcome the lesion without definitive treatment.

\section{Re-mineralization}

Re-mineralization is the initial step of WSLs improvement. Several products are available for such purpose in different forms like solutions, varnishes, creams, pastes and chewing gums which contain fluorides and/or casein phosphopeptideamorphous calcium phosphate and are necessary to apply more invasive techniques such as resin-infiltration, bleaching and micro-abrasion. This lesion should not be treated by the products containing higher concentrations of fluoride in incisors and canines as those caused tooth discoloration. ${ }^{64}$

\section{Bleaching}

Bleaching procedures show short range of aesthetic outcome and cause less enamel micro-hardness as well as teeth sensitivity ${ }^{65}$ Nevertheless bleaching with $10 \%$ carbamide peroxide as well as adding casein phosphopeptide-amorphous calcium phosphate is considered to incipient enamel caries without having any effect on enamel properties (mechanical and chemical) along with promoting in mineral gaining on subsurface of lesion. ${ }^{66}$ Bleaching with bleaching agents along 
with three different types of biomaterials such as nanohydroxyapatite, nano-BAG and nano-amorphous calcium phosphate soothe the unsatisfactory effects of bleaching as well as impede the irreversible damage over the enamel surface. ${ }^{67,68}$

\section{Micro-abrasion}

Micro-abrasion alone with the bleaching technique is an active method for the treatment of post orthodontic WSLs while the depth of lesion is less than $0.2 \mathrm{~mm} .{ }^{69}$ After debonding, micro-abrasion plays a good role by the process of salivary re-mineralization and continuous surface abrasion for improving lesions because of its invasive nature. While applying abrasive slurry of $6.6 \%$ (Opalustre) or $6 \%$ (Whiteness RM) hydrochloric acid with a brush on the enamel surface, it shows chemical and mechanical effects. 70

\section{Resin-infiltration}

A low-viscosity resin is used to infiltrate the WSL after completion of several steps like etching with $15 \% \mathrm{HCl}$ acid for 20 s then rinsing, drying and dehydration of the enamel surface with ethanol; which makes the enamel surface more permeable for triethylene glycol dimethacrylate-based resin to pass into the underlying porous structure caused to mask the WSL as well as reinforcing prismic structure of enamel. ${ }^{69}$ The masking effects rely on the depth of the lesion and cosmetic outcome of the treatment is more satisfactory in the beginning level known as active stage..$^{71,72} 1$ year followup study has shown that permanent cosmetic improvement can be achieved in post-orthodontic WSLs with this method. ${ }^{73}$ Other study has seen that no colour change occured after 2, 6, and 12 months, consecutively. ${ }^{74}$ However, previous study showed that satisfactory clinical performance can be obtained after 19 months from the treatment of WSLs associated with non-orthodontic etiology such as fluorosis, after trauma. ${ }^{75}$ An earlier study evaluated the colour improvement and stability of WSLs treated by fluoride, micro-abrasion or infiltration and found the acceptable result in favour of infiltration and micro-abrasion. ${ }^{70}$

\section{CONCLUSION}

The common side effect of fixed orthodontic treatment is WSLs. Therefore the responsibility of an orthodontist is to abate the risk of the patient having decalcification as a consequence of orthodontic treatment by instructing and motivating the patients for practicing excellent oral hygiene. Prophylaxis and management should be carried out by using high-fluoride toothpaste, gel, mouthwash, varnishes application, bonding agent RMGICs, pro-biotic, polyols, antiseptic, sealants, casein supplements, laser, tooth bleaching, micro-abrasion and resin infiltration.

\section{Disclosure of funding: Nil \\ Conflict of Interest: Nil}

\section{REFERENCES}

1. Fejerskov O, Nyvad B, Kidd EAM. Clinical and histological manifestations of dental caries. In Fejerskov O, Kidd EAM, editors. Dental Caries. The disease and its clinical management. Copenhagen: Blackwell Munksgaard. 2003; pp. 71-99

2. Batoni G,Pardini M,Giannotti A, Ota F, Guica MR, Gabrielle M.Effect of removable orthodontic appliances on oral colonisation by mutansstreptococciinchildren.Eur J Oral Sci 2001;109:388-92.

\section{https://doi.org/10.1034/j.1600-0722.2001.00089.x}

3. Petti S,Barbato E, Simonettid'ArcaA.Effect of orthodontic therapy with fixed and removable appliances on oral microbiota: a six-month longitudinal study.New Microbial 1997;20;55-62.

4. Rosenbloom RG, Tinanoff N, Salivary streptococcus mutans levels in patients before,during,and after orthodontic treatment. Am J OrthodDentofacialOrthop 1991;100:35-7. https://doi.org/10.1016/0889-5406(91)70046-Y

5. Maxfield BJ, HamdanAM, Tüfekçi E, Shroff B, Best AM, Lindauer SJ. Development of white spot lesions during orthodontic treatment: perceptions of patients, parents, orthodontists, and general dentists. Am J OrthodDentofacialOrthop. 2012 Mar; 141(3): 337-44. https://doi.org/10.1016/j.ajodo.2011.08.024

6. Lucchese A, Gherlone E. Prevalence of white-spot lesions before and during orthodontic treatment with fixed appliances. Eur J Orthod. 2013 Oct;35(5):664-8.

https://doi.org/10.1093/ejo/cjs070

7. Srivastava K, Tikku T, Khanna R, Sachan K. Risk factors and management of white spot lesion in orthodontics. J OrthodSci 2013;2:43-49.

https://doi.org/10.4103/2278-0203.115081

8. ØggardB.Prevalance of white spot lesions in 19-yearsolds; a study on untreated and orthodontically treated persons 5 years after treatment. Am J OrthodDentofacialOrthop 1989;96:423-7.

https://doi.org/10.1016/0889-5406(89)90327-2

9. Tufekci E, Dixon JS, Gunsolley JC, Lindauer SJ. Prevalence of white spot lesions during orthodontic treatment with fixed appliances. Angle Orthod. 2011; 81: 206-10. https://doi.org/10.2319/051710-262.1

10. Chapman JA, Roberts WE, Eckert GJ, Kula KS, Gonzàlez-Cabezas C. Risk factors for incidence and severity of white spot lesions during treatment with fixed orthodontic 
appliances. Am J OrthodDentofacialOrthop 2010;138:18894.

https://doi.org/10.1016/j.ajodo.2008.10.019

11. Arjun J, Brobakken BO, Prevalence of carious white spots after orthodontic treatment with multibondedappliances.Eur J Orthod 1986;8:229-34. https://doi.org/10.1093/ejo/8.4.229

12. O'Reilly MM,Featherstone JDB. Decalcification and remineralization around orthodontic appliances:an in vivo study.Am J OrthodDentofacialOrthop 1987;92:33-40. https://doi.org/10.1016/0889-5406(87)90293-9

13. ShunginD, OlssonAI,Perrson M Orthodontic treatmentrelated white spot lesions:a 14-year prospective quantitative follow-up, including bonding material assessment.Am J OrthodDentofacialOrthop 2010;138:136.el-8. 14. Karlinsey RL, Mackey AC, Stookey GK, Pfarrer AM. In vitro assessments of experimental $\mathrm{NaF}$ dentifrices containing a prospective calcium phosphate technology. Am J Dent. 2009 Jun;22(3):180-4.

15. Summit JB, Robbins JW, Schwartz RS. 3rd ed.ch.1. Hanover Park, IL: Quintessence publishing;2006. Fundamentals of Operative Dentistry:A Contemporary Approach;pp.2-4.

16. Øgaard B, Bishara SE, Duschner H. Enamel effects during bonding-debonding and treatment with fixed appliances. In: Graber TM, Eliades T, Athanasiou AE: Risk Management in Orthodontics: Experts Guide to Malpractice. Hanover Park, IL, Quintessence. 2004; 19-46 17. Lundström F, Krasse B. Streptococcus mutans and lactobacilli frequency in orthodontic patients; the effect of chlorhexidine treatments. Eur J Orthod. 1987;9:109-16. https://doi.org/10.1093/ejo/9.2.109

18. Scheie AA, Arneberg P, Krogstad O. Effect of orthodontic treatment on prevalence of Streptococcus mutans in plaque and saliva. Scand J Dent Res. 1984;92:211-7. https://doi.org/10.1111/j.1600-0722.1984.tb00881.x

19. Zachrisson BU, Zachrisson S. Caries incidence and oral hygiene during orthodontic treatment. Scand J Dent Res.

1971;79:394-401.

https://doi.org/10.1111/j.1600-0722.1971.tb02028.x

20. Sakamaki ST, Bahn AN. Effect of orthodontic banding on localized oral lactobacilli. J Dent Res. 1968;47:275-9. https://doi.org/10.1177/00220345680470021301

21. Balenseifen JW, Madonia JV. Study of dental plaque in orthodontic patients. J Dent Res. 1970;49:320-4.

https://doi.org/10.1177/00220345700490022101

22. Lundström F, Krasse B. Caries incidence in orthodontic patients with high levels of Streptococcus mutans. Eur J Orthod. 1987;9:117-21.

https://doi.org/10.1093/ejo/9.2.117

23. Chang HS, Walsh LJ, Freer TJ. The effect of orthodontic treatment on salivary flow, $\mathrm{pH}$, buffer capacity, and levels of mutans streptococci and lactobacilli. AustOrthod J. 1999;15:229-34.

24. Türkkahraman H, Sayin MO, Bozkurt FY, Yetkin Z, Kaya S, Onal S. Archwire ligation techniques, microbial colonization, and periodontal status in orthodontically treated patients. Angle Orthod. 2005;75:231-6.

25. Sukontapatipark W, el-Agroudi MA, Selliseth NJ, Thunold K, Selvig KA. Bacterial colonization associated with fixed orthodontic appliances. A scanning electron microscopy study. Eur J Orthod. 2001;23:475-84.

https://doi.org/10.1093/ejo/23.5.475

26. Smales RJ. Plaque growth on dental restorative materials. J Dent. 1981;9:133-40.

https://doi.org/10.1016/0300-5712(81)90087-7

27. Gwinnett AJ, Ceen RF. Plaque distribution on bonded brackets: A scanning microscope study. Am J Orthod. 1979;75:667-77.

https://doi.org/10.1016/0002-9416(79)90098-8

28. Forsberg CM, Brattström V, Malmberg E, Nord CE. Ligature wires and elastomeric rings: Two methods of ligation, and their association with microbial colonization of Streptococcus mutans and Lactobacilli. Eur J Orthod. 1991;13:416-20.

https://doi.org/10.1093/ejo/13.5.416

29. Lundström F, Krasse B. Streptococcus mutans and lactobacilli frequency in orthodontic patients; the effect of chlorhexidine treatments. Eur J Orthod. 1987;9:109-16. https://doi.org/10.1093/ejo/9.2.109

30. Gwinnett AJ, Ceen RF. Plaque distribution on bonded brackets: A scanning microscope study. Am J Orthod. 1979;75:667-77.

https://doi.org/10.1016/0002-9416(79)90098-8

31. Forsberg CM, Brattström V, Malmberg E, Nord CE. Ligature wires and elastomeric rings: Two methods of ligation, and their association with microbial colonization of Streptococcus mutans and Lactobacilli. Eur J Orthod. 1991;13:416-20.

https://doi.org/10.1093/ejo/13.5.416

32. Harvey WJ, Powell KR. Care of dental enamel for the orthodontic patient. AustOrthod J. 1981; 7: 70-6. 16. 33. Øgaard B, Rolla G, Øgaard B. Oral microbiological changes, long-term enamel alterations due to decalcification, and caries prophylactic aspects, in Brantley WA, Eliades T, eds: Orthodontic Materials: Scientific and Clinical Aspects. Stuttgart, Thieme. 2001; 123-142.

34. Davidson CL, Bekke-Hoekstra IS. The resistance of superficially sealed enamel to wear and carious attack in vitro. J Oral Rehabil. 1980;7:299-305.

https://doi.org/10.1111/j.1365-2842.1980.tb00448.x

35. Al-Mulla A, Karlsson L, Kharsa S, Kjellberg H, Birkhed 
D. Combination of high-fluoride toothpaste and no postbrushing water rinsing on enamel demineralization using an in-situ caries model with orthodontic bands. ActaOdontol Scand. 2010;68:323-8. https://doi.org/10.3109/00016357.2010.512863

36. Bergstrand F, Twetman S. A review on prevention and treatment of post-orthodontic white spot lesions - Evidencebased methods and emerging technologies. Open Dent J. 2011;5:158-62.

https://doi.org/10.2174/1874210601105010158

37. Feng CH, Chu XY. Efficacy of one year treatment of icon infiltration resin on post-orthodontic white spots. Beijing Da XueXueBao. 2013;45:40-3.

38. Richter AE, Arruda AO, Peters MC, Sohn W. Incidence of caries lesions among patients treated with comprehensive orthodontics. Am J OrthodDentofacialOrthop. 2011;139:65764.

https://doi.org/10.1016/j.ajodo.2009.06.037

39. Bishara SE, Ostby AW. White spot lesions: Formation, prevention, and treatment. SeminOrthod. 2008;14:174-82. https://doi.org/10.1053/j.sodo.2008.03.002

40. Sudjalim TR, Woods MG, Manton DJ. Prevention of white spot lesions in orthodontic practice: A contemporary review. Aust Dent J. 2006;51:284-9.

https://doi.org/10.1111/j.1834-7819.2006.tb00445.x

41. Bahoum A, Bahije L, Zaoui F. Enamel demineralization in orthodontics. Systematic use of fluoride in prevention and treatment. SchweizMonatsschrZahnmed. 2012;122:937-47. 42. Benson PE, Parkin N, Dyer F, Millett DT, Furness S, Germain P. Fluorides for the prevention of early tooth decay (demineralised white lesions) during fixed brace treatment. Cochrane Database Syst Rev. 2013;12:CD003809. https://doi.org/10.1002/14651858.CD003809.pub3

43. Benson PE, Parkin N, Millett DT, Dyer FE, Vine S, Shah A. Fluorides for the prevention of white spots on teeth during fixed brace treatment. Cochrane Database Syst Rev. 2004;3:CD003809.

https://doi.org/10.1002/14651858.CD003809.pub2

44. Chadwick BL, Roy J, Knox J, Treasure ET. The effect of topical fluorides on decalfication in patients with fixed orthodontic appliances: a systematic review. Am J OrthodDentofacialOrthop. 2005; 128: 601-6.

https://doi.org/10.1016/j.ajodo.2004.07.049

45. Gwinnett AJ, Buonocore MG, Sheykoleslam Z. Effect of fluoride on etched human and bovine tooth enamel surfaces as demonstrated by scanning electron microscopy. Arch Oral Biology. 1972; 17: 271-8.

https://doi.org/10.1016/0003-9969(72)90210-5

46. Boyd RL. Comparison of three self-applied topical fluoride preparations for control of decalcification. Angle Orthod.1993;63:25-30. .
47. Garcia-Godoy F. Shear bond strength of a resin composite to enamel treated with an APF gel. Pediatric Dentistry. 1993; 15(4): 272-4.

48. Demito CF, Rodrigues GV, Ramos AL, Bowman SJ. Efficacy of a fluoride varnish in preventing whitespot lesions as measured with laser fluorescence. J ClinOrthod. 2011; 45: 25-9.

49. Twetman S, Keller MK. Probiotics for caries prevention and control. Adv Dent Res. 2012;24:98-102. https://doi.org/10.1177/0022034512449465

50. Sengun A, Sari Z, Ramoglu SI, Malkoç S, Duran I. Evaluation of the dental plaque $\mathrm{pH}$ recovery effect of a xylitol lozenge on patients with fixed orthodontic appliances. Angle Orthod. 2004;74:240-4.

51. Beyth N, Redlich M, Harari D, Friedman M, Steinberg D. Effect of sustained-release chlorhexidine varnish on Streptococcus mutans and Actinomycesviscosus in orthodontic patients. Am J OrthodDentofacialOrthop. 2003;123:345-8.

https://doi.org/10.1067/mod.2003.19

52. Kronenberg O, Lussi A, Ruf S. Preventive effect of ozone on the development of white spot lesions during multibracket appliance therapy. Angle Orthod. 2009;79:64-9. https://doi.org/10.2319/100107-468.1

53. Shen P, Cai F, Nowicki A, Vincent J, Reynolds EC. Remineralization of enamel subsurface lesions by sugar-free chewing gum containing casein phosphopeptide-amorphous calcium phosphate. J Dent Res. 2001;80:2066-70. https://doi.org/10.1177/00220345010800120801

54. Cross K, Huq N, Stanton D, Sum M, Reynolds E. NMR studies of a novel calcium, phosphate and fluoride delivery vehicle-? S1-casein (59-79) by stabilized amorphous calcium fluoride phosphate nanocomplexes. Biomaterials. 2004;25:5061-9.

https://doi.org/10.1016/j.biomaterials.2004.01.045

55. Reynolds EC. Casein phosphopeptide-amorphous calcium phosphate: The scientific evidence. Adv Dent Res. 2009;21:25-9.

https://doi.org/10.1177/0895937409335619

56. Iijima Y, Cai F, Shen P, Walker G, Reynolds C, Reynolds EC. Acid resistance of enamel subsurface lesions remineralized by a sugar-free chewing gum containing casein phosphopeptide-amorphous calcium phosphate. Caries Res. 2004;38:551-6.

https://doi.org/10.1159/000080585

57. Cochrane NJ, Cai F, Huq NL, Burrow MF, Reynolds EC. New approaches to enhanced remineralization of tooth enamel. J Dent Res. 2010;89:1187-97.

https://doi.org/10.1177/0022034510376046

58. Pithon MM, Santos Mde J, de Souza CA, LeãoFilho JC, Braz AK, de Araujo RE, et al. Effectiveness of fluoride 